\title{
Tightening sanctions for physician sexual misconduct
}

Cite as: CMAJ 2018 November 26;190:E98-9. doi: 10.1503/cmaj.109-5687

Posted on cmajnews.com on Nov. 7, 2018.

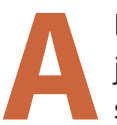

lberta has become the latest jurisdiction to propose stricter sanctions for physicians found guilty of sexual misconduct with patients. Health minister Sarah Hoffman introduced a bill recently that would impose mandatory penalties, require more transparency from regulatory colleges and increase support for victims.

"Women, and all Albertans, deserve to feel safe when they put their trust in health care professionals," Hoffman said in a statement. "For too long, Albertans were left in the dark about disciplinary histories, as we continued to hear disturbing stories of offending professionals being allowed to practise again."

Under the proposed legislation, doctors or other health professionals found to have committed sexual abuse will have their licences revoked. A finding of sexual misconduct will result in licence suspension. No application for reinstatement could be made for five years. Regulatory colleges would be required to maintain public websites that include their members' disciplinary history for sexual abuse and sexual misconduct, including conditions on practice permits.

Steve Buick, a spokesman for the College of Physicians and Surgeons of Alberta, says the college is on board with the new legislation. "We've been consulted and had substantial input, and the legislation is well aligned with our own position," he said.

The college already posts the results of disciplinary hearings on its website and has recently been pushing for stiffer penalties for sexual misconduct. For example, in a recent hearing a doctor was found guilty of professional misconduct, includ- ing inappropriate sexual relations with patients. The college wanted his licence to be revoked, but the hearing tribunal instead suspended him for 18 months and placed restrictions on his practice permit. The college is appealing the decision and pushing for revocation. "We are taking the tecting patients from sexual abuse. A bill signed into law in California in September requires doctors on disciplinary probation for sexual misconduct and other offences to notify their patients, making it the first state in the US to introduce that requirement.

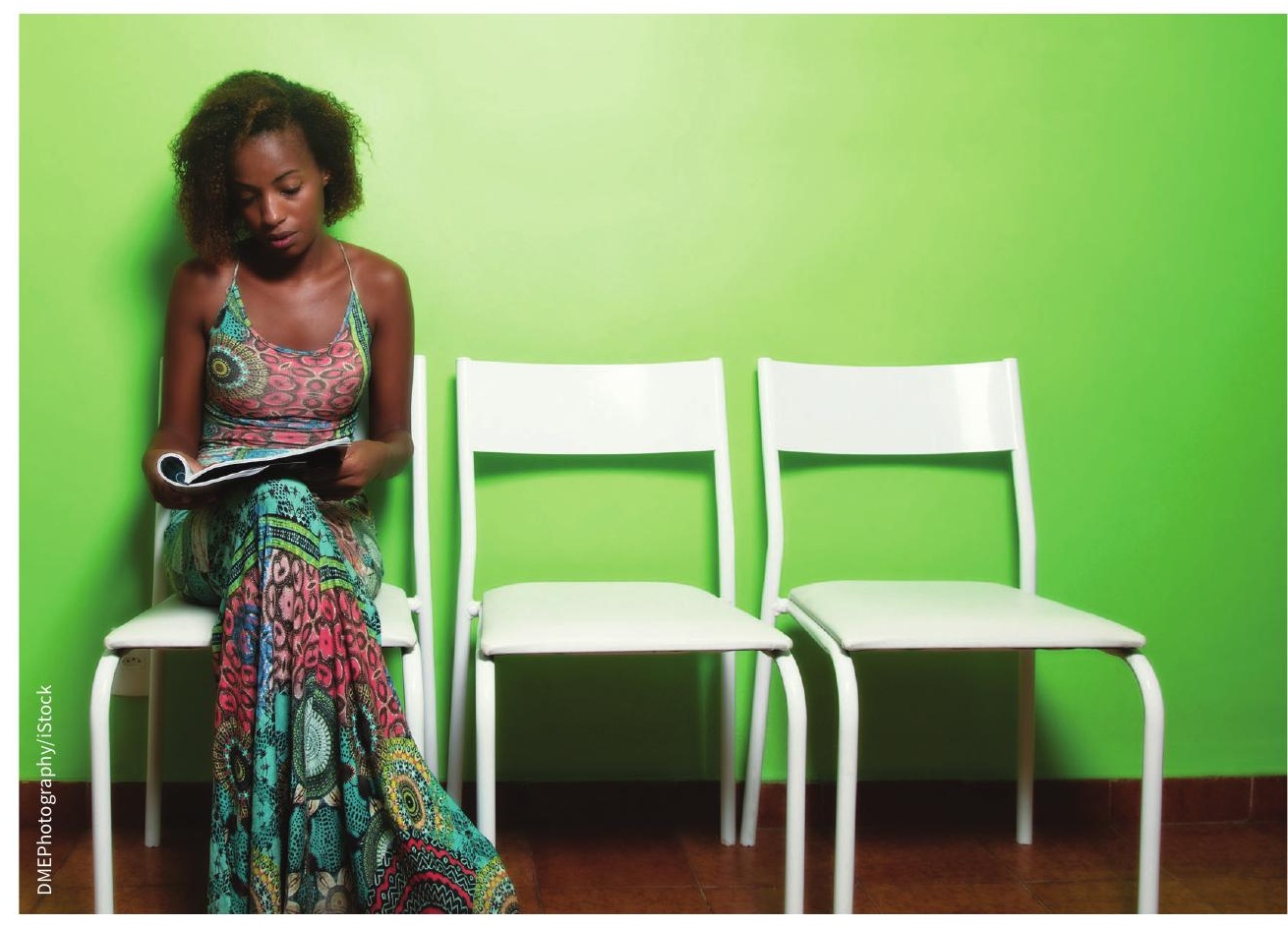

Patients in physician waiting rooms often have no idea about the disciplinary histories of the doctors they're about to see.

very rare step of appealing our own tribunal," said Buick.

Alberta is not alone in pursuing stiffer penalties for sexual misconduct. Hoffman's bill is modelled on a similar law in Ontario that came into effect in May 2018, making those two provinces the only ones to introduce laws aimed specifically at pro-
Jerry Hill, the California State Senator who sponsored the bill, says proactive patient notification is necessary because $30 \%$ of physicians put on probation in California reoffend. Many are sole practitioners with no one to ensure they follow the terms of their sentence. The Medical Board of California already has an online 
registry that lists when and why doctors are on probation, but few people check it. "It takes a long time, and no one looks up their doctor," says Hill. "They don't know how, and medicine is such a wellrespected profession that they don't think to ask the question." It's something Hill now does as a matter of course, for both himself and his family, and he discovered that his daughter's physician has been accused of prescribing opioids improperly.

That kind of mandatory notification has not caught on in Canada, though regulatory colleges have the power to require it if deemed necessary. It is used occasionally in Alberta, said Buick. But cases that would warrant patient notification are rare, according to Dr. Ed Schollenberg, registrar of the College of Physicians and Surgeons of New Brunswick. A physician who committed a serious sexual offence would likely lose their licence, and a doctor on suspension is not likely to return to work soon, "so the question is kind of moot," he said.

New Brunswick sees so few cases of sexual misconduct that the issue has not come up, he added. Besides, there appears to be little demand for more proactive notification in the province. In one recent case involving an affair between a doctor and patient, there was a huge backlash in the community over the physician's suspension. "Requiring public notification is a real threshold to cross," he said.

Dr. Marie Bismark, who studies law and public health at the University of Melbourne in Australia, says informing patients of disciplinary actions against their physicians should be thought of in the same way as getting informed consent for sur- gical procedures. "From a patient's perspective, is the fact that a doctor had previous disciplinary problems as important as the risk of a rare complication in surgery? I'd say the answer is yes, and it may be more important," she said.

The shift toward stricter punishments for sexual misconduct and more transparency is part of a broader change in medical practice, says Bismark, driven in part by a greater awareness of the problems with sexual harassment and abuse in society. Senator Hill agrees. This was his third attempt to get his bill passed, and he says the rise of the \#MeToo movement and the conviction of Dr. Larry Nassar for the abuse of hundreds of young girls as team doctor for USA Gymnastics played major roles in its success.

Brian Owens, St. Stephen, NB 